\title{
Foucaults Dispositive
}

\section{The Perspicacity of Dispositive Analytics in Organizational Research}

\author{
Raffnsøe, Sverre; Gudmand-Høyer, Marius T.; Thaning, Morten Sørensen
}

Document Version

Accepted author manuscript

Published in:

Organization

DOI:

$10.1177 / 1350508414549885$

Publication date:

2016

License

Unspecified

Citation for published version (APA):

Raffnsøe, S., Gudmand-Høyer, M. T., \& Thaning, M. S. (2016). Foucaults Dispositive: The Perspicacity of Dispositive Analytics in Organizational Research. Organization, 23(2), 272-298.

https://doi.org/10.1177/1350508414549885

Link to publication in CBS Research Portal

\section{General rights}

Copyright and moral rights for the publications made accessible in the public portal are retained by the authors and/or other copyright owners and it is a condition of accessing publications that users recognise and abide by the legal requirements associated with these rights.

Take down policy

If you believe that this document breaches copyright please contact us (research.lib@cbs.dk) providing details, and we will remove access to the work immediately and investigate your claim. 


\section{Foucault's Dispositive: The Perspicacity of Dispositive Analytics in Organizational Research}

\section{Sverre Raffnsee, Marius Gudmand-Heyer, and Morten S. Thaning}

Journal article (Post print version)

Citation: Foucaults Dispositive : The Perspicacity of Dispositive Analytics in Organizational Research. / Raffnsøe, Sverre; Gudmand-Høyer, Marius T.; Thaning, Morten Sørensen. In:

Organization, Vol. 23, No. 2, 2016, p. 272-298.

First published online: September 17, २014.

DOI: 10.1177/1350508414549885

Uploaded to Research@CBS: March २०16 


\title{
Foucault's dispositive: The perspicacity of dispositive analytics in organizational research
}

\author{
Sverre Raffnsøe, Marius Gudmand-Høyer, Morten S. Thaning \\ Copenhagen Business School, Denmark
}

\begin{abstract}
While Foucault's work has had a crucial impact on organizational research, the analytical potential of the dispositive has not been sufficiently developed. The purpose of this article is to reconstruct the notion of the dispositive as a key conception in Foucault's thought, particularly in his lectures at the Collège de France, and to develop dispositional analytics with specific reference to matters of organization.

Foucault's dispositional analysis articulates a history of interrelated social technologies that have been constructed to organize how we relate to each other. The article distinguishes various dispositional prototypes. It shows how dispositional analytics leads the way beyond general periodizations and established dichotomies such as the either-or of the discursive and non-discursive, power and freedom, determinism and agency; and it demonstrates how dispositional analytics can contribute to a more complex understanding of organizational dynamics, power, strategy, resistance and critique.

Dispositional analytics allows for a new interpretation and use of Foucault in relation to organization studies.
\end{abstract}

Keywords:

Foucault, dispositive, analytics, law, discipline, security, power, resistance, critique 


\section{Introduction: Foucault's inheritance in organization studies}

As in many other fields of research, the legacy of Michel Foucault has become almost ubiquitous in management and organization studies (Carter et al., 2002; Välikangas and Seeck, 2011; McKinlay, Carter and Pezet, 2012). This overarching presence appears to be especially marked within British organization studies (Carter, 2008) and within Critical Management Studies in particular (McKinlay et al., 2012).

Across this reception, one particular attraction to Foucault's philosophical style has been its ability to push organizational analysis in new directions and beyond a pre-occupation with already established categories. Foucault is regarded as a way to 'reject the notion of perceiving the subject matter of organization theory exclusively as the bounded entity that commonly attracts the label "organization"” (Knights, 2002: 576), but also to avoid returning to the contrary term and entity of the individual (Newton, 1998). Transgressing received dichotomies between such 'dualistic categories', a Foucauldian approach enables us to focus on 'practices and processes of organizing [...] rather than on entities' (Weiskopf and Loacker, 2006: 397; see also Willmott, 2011). Rendering concrete modes of organization intelligible, this level of analysis similarly evades the risk of reducing the organization, the individual, and the practices and processes of these efforts to a mere effect of the restraints that an even more basic entity or unity, society, imposes upon us (Weiskopf and Loacker, 2006).

This well-established line of thought has certainly produced important insights and new research perspectives, not only in the early reception (e.g. Knights, 1992; Townley, 1994; 1995; 2002; Burrell, 1988; McKinlay and Starkey, 1998; Newton, 1998; McKinlay, 2002; Starkey and Hatchuel, 2002; Knights, 2002) but recently as well (Caldwell, 2007; Al-Amoudi, 2007; Barratt, 2008; Carter, 2008; Ahonen and Tienar, 2009; Bardon and Josserand, 2011; 
Leclercq-Vandelannoitte, 2011; McKinlay and Wilson, 2012; Butler and Dunne, 2012). Still, given that this vein of organizational analysis has stressed 'the principles and processes of organizing wherever it occurs' (Knights, 2002: 577), the reception of Foucault's thought in organizational studies may, up to now, appear biased in certain respects. This tendency has been furthered as Foucault's work is typically compartmentalized into a succession of archeological, genealogical, and aesthetic or ethical phases (Knights, 1992; Starkey and Hatchuel, 2002; Välikangas and Seeck, 2011). In particular, the reception of Foucault in organization studies has, already from the beginning, tended to focus on his second genealogical phase and especially his analysis of discipline in Discipline and Punish (Knights (2002: 582), which may have led to an overrepresentation of analyzing processes of individualization in terms of limitation, repression, and subjugation (Weiskopf and Loacker, 2006: 397), and a corresponding need to discuss the possibility of resistance (Knights, 2002: $582)$.

This bias in reception is of consequence for organization studies, as it affects the ways in which the processes and conditions of organization may be analyzed and thus the way crucial aspects of the organization appear. Decontextualized and recontextualized within organizational studies (Jones, 2002), certain parts of Foucault's work have been markedly prioritized to the detriment of others. Thus 'deformed', Foucault has become his own discourse in organization studies that we may need to distance ourselves from, by introducing new productive approaches and notions of analysis.

Indeed, an analytical prospect of this particular kind is Foucault's crucial notion of the dispositive (le dispositif), which has been notably absent from the common/dominant reception of his work in organizational research so far. At first glance, this lacuna may seem logical, as a seminal introduction to Foucault, written by Dreyfus and Rabinow (1982: 119- 
21), rashly contested the notion of le dispositif, calling it extremely vague in terms of methodological rigor and impossible to translate into English other than with the equally indistinct term 'apparatus'. However, in the introduction to The Essential Foucault, the same Rabinow, along with Rose, has since endorsed 'the dispositive' as 'one of the most powerful conceptual tools introduced by Foucault' (Rabinow \& Rose, 2003: xv). Rabinow and Rose now find that the notion cuts across inflexible categories, such as institutions, classes, and cultures together with ideas, ideologies, and beliefs. This is because the dispositive connects them in unexpectedly productive ways for reflection in general and research in particular. As an analytical notion characterized both by inclusiveness and complexity, the dispositive has already been object of a considerable reception in other branches of social research, either in its own right (e.g. Olivier, 1988; Deleuze *1989/1992; Bussolini, 2010; Legg, 2011; Agamben, *2005/2009) or especially in relation to Governmentality Studies (e.g. Bell, 2006; Aradau and Munster, 2007; Elden, 2007; Dillon, 2007; Dillon and Lobo-Guerrero, 2008; 2009; Muller, 2008; Villadsen, 2008; Collier, 2009), Discourse Theory and Analysis (e.g. Jäger, 2001; Bührmann and Schneider, 2008; Caborn, 2007), or Science and Technology Studies (e.g. Jacquinot-Delaunay and Monnoyer (eds), 1999; Callon and Muniesa, 2003; Beuscart and Peerbaye (eds) 2006).

The primary purpose of this article is to give substance to the notion of the dispositive as a key conception in Foucault's work and a powerful analytical tool with specific reference to matters of organization. As developed in his annual lectures at Collège de France, most notably the courses held in 1978 and 1979 (Foucault *2004a/2008; *2004b/2009), we shall see how the dispositive forms a crucial constituent of societal analysis in Foucault's oeuvre on par with the more familiar analytics of discourse, discipline, power/knowledge, subjectivity, and subjectification. Indeed, it will become clear that it forms a disregarded intermediary 
between these. Foucault's dispositional analysis can be articulated as a history and a typology of connected social technologies, as well as a potent analytical approach to social reality. As an interconnecting, broad, and diversified analytical tool, the notion permits an alternative access to the circumstances under which organizing and organizations take place. Deferring attention from the organization as an entity to a larger social field, without reducing the former to a given, even more fundamental entity (e.g. society), dispositional analysis elucidates conditions for organizing and organizational processes, which managers and concrete organizations as well as organizational theory need to address and take into consideration. As the term 'dispositive' suggests, the dispositional analysis manages to do so by virtue of focusing on the appearance of certain social dispositions or inclinations and by articulating the way these arrangements affect social interaction and organizational behavior. Since it permits us to lay bare a social formation and transformation of the conditions for human agency, which have a determinate impact on how we think, feel, act, and imagine our future without determining what we do completely, dispositional analysis could lead the way beyond a number of recurring dualisms experienced as problematic in current organizational theory (Weiskopf and Loacker, 2006). For an organizational theory that is grappling with the decisive and close 'relationship between agency and change, resistance and power in organizations and society' (Caldwell, 2007: 769), dispositional analysis suggests a way to proceed. Shifting focus towards an analysis of the possibilities of agency and change, this approach avoids a mechanistic conception of organizations, even as it points beyond a received dichotomy between power and freedom in organization studies, implicitly suggesting a negative conception of power as restraint and repression of human freedom (Weiskopf and Loacker, 2006: 398). It questions the perception of organizations as closed entities that primarily limit and control behavior, even as it problematizes a sharp distinction between and 
inside and an outside the organization, and between the individual and the collective (Välikangas and Seeck, 2011). Articulating an on-going modulation of our dispositions, dispositional analysis evades the 'oscillation between determinism and counteraction' (Caldwell, 2007: 779). Questioning well-known dichotomies, the analysis even permits confronting a conception of history as consisting of isolated phases and articulates ambivalences in the current organization of work, not as isolated, but as interconnected occurrences (Weiskopf and Loacker, 2006: 413-14).

In so far as they remain within the received dualisms of power and freedom, determinism and counteraction, structure and agency, the inside and the outside of an organization, organizational studies are unable to keep up with, diagnose, and analyze important strands in modern organizational life. Theoretically and analytically, the 'either-or' inherent in the said dualisms needs to be replaced by the perception of a 'both-and' approach that permits a demonstration of how elements of binary oppositions appear in their interrelatedness as part of the same correlation.

To achieve its aim, the article proceeds in four sections. Beginning with a short outline of the scarce reception of the term 'dispositive' within organization studies, the first section details the critical and constructive purpose of the contribution, with special regard to the current status of utilizing Foucault's thought within organizational studies. The second section continues with an exposition of the analytical semantics of the dispositive. It seeks to clarify its different meanings, while also emphasizing how Foucault did not invent the seemingly artificial term 'dispositive', but makes use of the diverse semantics of a common French word, while also expanding it to fit his analytical endeavor more adequately. The third section proceeds by spelling out the manner in which Foucault, in his 1978 and 1979 lectures, develops dispositional analytics as an integral component of a history of 
different yet interrelated dispositives, or major societal technologies. Importantly, Foucault differentiates between particularly significant dispositional prototypes, namely the legal dispositive, the disciplinary dispositive, and dispositives of security. These types are not used to generalize and periodize various societal formations, but are employed in order to study the problematization of significant social phenomena or experiences in compliance with a 'system of correlation' (*2004a: 10/2007: 10) between the different dispositives. The final section shows how Foucault's dispositional analytics may contribute to and transform the study of organizational themes and practice, such as organizational discourses, power and freedom, resistance and critique, and affect the very object and level of investigation for organizational theory.

As a last prefatory point, we translate the French dispositif not as 'apparatus' but as 'dispositive'. We agree with Bussolini that 'crucial etymological and conceptual ties [are] occluded by “apparatus"” (2010: 86) and have chosen to replace this common English rendering since only 'dispositive' carries with it the connotations of 'something that disposes or inclines', or 'has the quality of disposing or inclining' (OED), which is crucial for the mode of inquiry pertaining to dispositional analysis. For the same reason we often re-translate the quotations from Foucault from the original French texts (marked with *), but usually as close to the existing English versions as possible.

\section{The reception of the dispositive and problems of periodization}

In the absence of a more elaborate discussion of its systematic character and general role in Foucault's work, the dispositive is often presented in organization studies as subordinate and reducible to other crucial concepts or as fundamentally open and indistinct. Using 'dispositive' and 'disciplinary apparatus' 'interchangeably,' Ahonen and Tiniary (2009: 
675fn.) link the dispositive very closely to discipline, while Jackson and Carter (1998: 60) conceptualize the dispositive as 'the 'apparatus' which, operationalizes governmentality,' since it is the 'apparatus of control which produces submission and compliance to the demands of governance'. Incidentally, in 2012 the editorial to a special issue of Organization drew attention to the prospects for the term by noting that it is 'a concept with deep theological implications and a much larger horizon than normally acknowledged.' (Sørensen et al., 2012: 273). Still, even if the editors refer to Foucault and claim that the notion should be 'influential in organization studies' (ibid.), this treatment of the dispositive remains embedded in Agamben's (2009: 13) recent exposition of its signification.

In a recent study, however, Weiskopf and Munro (2011: 687) present a very creditable characterization and juxtaposition of 'the apparatuses (dispositifs) of discipline and those of security' that is not only apposite in the matter of Foucault's lecture courses from 1978-1979, but also in regard to the analytical approach to be outlined here. As such, our contribution draws upon the investigation of Weiskopf and Munro (2011: 699). Whereas Weiskopf and Munro discuss the concept of dispositive rather expeditiously in the context of a specific analysis, focusing on 'the concept of human capital and its role within the development of enterprise culture', our contribution concentrates more decisively on a thorough interpretation of Foucault's notion of the dispositive and on developing his dispositional analytics as an overarching analytical framework. We seek to develop a frame of methodological reflection for further empirical analysis of problems of organization that consciously employs this 'powerful conceptual tool' (Rabinow \& Rose, 2003: xv).

To achieve this end, it is necessary first to address a problem that surfaces even in the otherwise refined uses of the dispositive for specific analysis. On the face of it, this problem has to do with the common penchant for pinning down certain consecutive historical epochs 
that Foucault seems to discern from each other (Knights, 2002; Jacques, 1996). Separated by radical shifts that seem to turn everything upside down, these epochs may come close to being all-embracing, unequivocal contexts that follow and replace each other, thus re-presenting society in general at a certain historical point. Even if only circuitously, this propensity to represent and reify all-embracing societal shifts may have been triggered off by Gilles Deleuze's pioneering and influential reception of Foucault's notion of the dispositive (cf. e.g. O’Connor, 1997; Abadía, 2003; Muller, 2008; David-Ménard, 2008; Villadsen, 2008). The problem to be addressed and mended is therefore that Deleuze's reading, in spite of its obvious and original qualities, has not only obscured central features of the dispositives as operationalized in Foucault's analysis, but has also left a confounding mark on organizational theory. The strong emphasis on periodization found in Deleuze prevails in the organizational reception of the dispositive and precludes organization studies from realizing the analytical potential of the concept.

Based on the important observation that 'Foucault's philosophy often presents itself as an analysis of concrete dispositives', Deleuze (*1989: $185 / 1992: 159)$ was possibly the first to emphasize the crucial importance of this, defining it as 'a tangle [écheveau], a multi-linear ensemble,' which is 'composed of lines, each having a different nature,' each of them 'broken and subject to changes in direction, bifurcating and forked, and subject to derivation' (*1989: 185/1992: 159). At the same time, however, it is also the achievement of Deleuze's pioneering and influential reception of the dispositive (cf. e.g. O’Connor, 1997; Abadía, 2003; Muller, 2008; David-Ménard, 2008; Villadsen, 2008), to have associated Foucault's 'philosophy of dispositives' (*1989: 188/1992: 162) with his own famous proposition concerning the coming into being of 'Control Societies' (*1990/1995), which have had a considerable reception within critical organization studies (Munro, 2000; Fleming and Spicer, 
2004; Weiskopf and Loacker, 2006; Martinez, 2010). In this context Deleuze claimed that while it 'is sometimes thought that Foucault painted the picture of modern societies in terms of disciplinary dispositives in opposition to the older dispositives of sovereignty', this should not be the case, as 'the disciplines Foucault described are the history of what we gradually cease to be, whereas our actuality is taking shape in dispositions of open and continuous control' (*1989: 191/162). Consequently, he develops Foucault's notion of dispositive by suggesting a succession of various societies, namely 'societies of sovereignty', 'disciplinary societies', and 'societies of control' (*1990: 240-41/1995: 177-78), each dominated or permeated by a particular dispositive. The problem here is not only that Deleuze paints Foucault as recognizing 'a society of control' as our imminent future (Deleuze, *1990: 241/1995: 178), in spite of very little in Foucault's published work testifying to any overt interest in contemporary control (cf. Lopdrup-Hjorth, 2013). In fact, in most discussions concerning control, Foucault explicitly associates this notion with the operations of discipline (cf. Foucault, 2007: 4,16,32,39,95,351,353). Of even greater importance is that Deleuze comes close to suggesting a simple succession of dispositional epochs, marked by a sharplycut periodization and sustained generalization of societal formations. Both of these are foreign to Foucault.

This problematic trait in Deleuze's account resembles a number of accounts within organizational research dealing with categories or elements in Foucault's thinking, which are closely related to the dispositive. For instance, the tendency surfaces in Knights' (2002) influential study on Foucault and organizational analysis, apparently combining the succession of societal diagnoses with the common periodization of Foucault's work. In spite of his reservations as to present 'what might be seen as a classification of Foucault's work', and in spite of urging us not to see these 'developments in evolutionary terms', Knights 
(2002: 578-579) nevertheless presents a 'Foucauldian Edifice' by way of which a general societal periodization is maintained. Schematically, he lays out a succession of societies, 'premodern', 'modern', and 'post-modern', correlative to or acted upon by 'processes of individualization' (Knights, 2002: 579). The same tendency lingers on in a more recent study by Weiskopf and Loacker (2006: 401-402), now with the introduction of the 'postdisciplinary' as a development of Deleuze's control society.

We therefore present dispositional analysis as an alternative analytic framework, with the aim of substantiating how Foucault explicitly conceived of this by way of countering epochal periodization and generalizing diagnosis. A refined and differentiated notion of the dispositive, in contrast, permits eschewing the problematic conception of Foucault and its reductive consequences for the critical investigations of organization studies. Instead, the dispositional analysis invites us to investigate to what extent organizations, management, and decision making are affected by, relate to, and further develop various given dispositions. It forces us to examine where these inclinations might take us and remain critical all the while (Parker and Thomas, 2011).

\section{The semantics and characteristics of the dispositive}

In everyday French, the term le dispositif often describes an arrangement set up for a specific purpose, also designed to have immediate effect (Jacquinot-Delaunay and Monnoyer, 1999). A well-known example would be un dispositif d'information at a railway station, presenting passengers track numbers along with a timetable of departures and arrivals. Currently, the notion is often used within the domain of new forms of information, communication, and media formats to describe how these may need organization, material resources, technological knowhow, formation of inputs, as well as reception of outputs. 
Even if the equivalent of the French word in English, the dispositive, is now obsolete, this translation is still preferable, because it covers almost the same semantic field as the French word (OED 2009,s.v.). Etymologically, in French as well as in English, the notion derives from the Late Latin dispositivus, a substantive form of the adjective under the same name. Both the adjective and the substantive are themselves derivatives of the Latin verb dis-pōnăre (lit. 'to set apart'), which is generally referring to such endeavors as 'to set in order,' 'to arrange or array,' 'to dispose' or 'to form.' The older connotations of the word dispositive are relevant for understanding its significance in Foucault's body of work. Hence, the dispositive subsists, although anachronistically, as something that 'is characterized by a special disposition or appointment'; it has 'the quality of disposing or inclining', as often as 'opposed to effective' and therefore nearly as 'preparatory, conducive, contributory' (OED 2008,s.v.). This becomes even clearer as a technical term in French (Le Petit Robert 2008,s.v.). In a military context, dispositive refers to a number of means in correlation to a given plan (e.g. dispositif d'attaque, dispositif de defence). But if a military strategy designates the process of planning, the dispositive would designate the very operation of the plan in time and space, with the means at hand, and with regard to the characteristics of the adversary. In a legal context, a dispositive refers to the closing, effective part of a lawful text. It specifies the relevance and effect of the declaration, especially how and why it is to be put into practice, as opposed to the preamble containing the purpose of the law, and to the statute itself formulating the specific legal command. In a technical sense the dispositive refers to the plan according to which the different components are in actuality organized in a given apparatus. As in the military context, the technical dispositive points to a situation, which is simultaneous with the operation of the formation, but with the addition that this formation can 
be mapped out in such a way that the given plan can be extracted, transposed to, and incorporated into other situations.

Althusser, Lyotard, or Baudry all used the dispositive as a central concept prior to Foucault, respectively discussing the 'conceptual dispositive' of the all-pervading ideology of the capitalistic state (Althusser, 1970), the 'libidinal dispositive' of human life and existence (Lyotard, 1973), and the 'cinematic dispositive' of the screen situation (Baudry, 1975). Within this setting, Foucault seems to have employed the notion as a rather unqualified 'dispositive of power' in his $1973-1974$ lectures on psychiatry in the $19^{\text {th }}$ century $(* 2003$ : 14/2006: 13).

During a roundtable in 1977, Foucault, seemingly for the first time, was asked directly: 'What is the meaning or the methodological function for you of this term, dispositive?' (*1977: 299/1980: 194). To this question he responded:

What I am trying to pick out with this term is, first of all, a thoroughly heterogeneous ensemble consisting of discourses, institutions, architectural forms, regulatory decisions, law, administrative measures, scientific statements, philosophical, moral and philanthropic proportions - in short: the said as much as the unsaid (Foucault *1977: 299/1980: 194).

Apparently, Foucault does not perceive the distinction between discursive fields and that which is non-discursive and of a more material kind (cf. Jäger 2001) as an all-encompassing, particularly important dichotomy. Instead, he was preoccupied with the way in which the elements of the dispositive interrelate. In the roundtable, Foucault therefore also defines the dispositive itself as 'the network [réseau] that can be established between these elements' (*1977: 299/1980: 194). The dispositive is concurrently a grouping of heterogeneous components, tangibles, and intangibles, situated within an arrangement, as well as the 
transversal set of connections between these components. The dispositive is of a relational nature, rather than of a substantial kind.

Foucault also emphasizes the modifiability of the dispositive, allowing the various elements to alter their position and produce new distributions (cf. Rabinow, 2003). In this sedimentary process, which Foucault designates 'the strategic completion of the dispositive' ( 1977 : 299/1980: 197), the different aspects of the dispositional arrangement not only make recourse to various political programmes, organizational distributions, or special instruments for the exercise of power (cf. *1975: 207/1977: 205), but also to analyses, reflections, calculations, or similar procedures (cf. *2004: 112/2007: 108-109). He can therefore characterize the dispositive as 'strategies of relation of forces supporting, and supported by, types of knowledge' (cf. *1977: 301/1980: 196).

Dispositional analysis therefore seeks to capture a regularity in historical processes. An analysis of dispositives rests on the view that different social acts alter what has been and that history in this way is a constant repetition of minor ruptures (cf. Foucault *1984). It also rests on the assumption that it is possible to establish a level of analysis, in which regularity is made visible in the processes of becoming. More generally, the dispositive should therefore be conceived of as the normative arrangement that subsequently seems to have emerged through the analyzed acts or events and as a result of their interaction. In retrospect, each of the social events seems to be derived from the dispositive they concurrently assist in creating.

\section{Dispositives as societal technologies}

The general notion of the dispositive is characterized by inclusiveness, relationality, modifiability, and non-determinism. This is why it is best understood when employed in actual dispositional analysis, as Foucault paradigmatically does in his 1978 lectures at the 
Collège de France. Foucault begins these lectures by pointing out how history can be analyzed as a history of major technologies or dispositives ( $\left.{ }^{*} 2004 \mathrm{a} / 2007\right)$. An analysis of dispositives of this type would also imply a history of dispositives and their interrelations. The history of principal, societal technologies differs from what Foucault calls 'a history of techniques in the proper sense of the word' ('2004a: 10/2007: 8), i.e. a history that merely focuses on the rise and fall of various means employed to deal with certain surroundings. The dispositional analysis of the history of technology is not content to merely describe, for instance, when solitary confinement was introduced in prisons. Instead it focuses on the 'far more global but also more blurred history of correlations which occasion that, in a given society and for a given sector, a technology will be installed' ("2004a: 10/2007: 8). Foucault's own critical analysis thus entails placing the various techniques, such as solitary confinement, within a more comprehensive dispositional history of technology. An analysis of dispositives seeks to account for how objects, practices, events, and experiences that are usually taken for granted, come into existence only in the interaction between the dispositives. Thus, Foucault seeks to demonstrate that they do not exist as objects or as pure, physical realities - they are actually constructed. At the same time, however, Foucault ( $\left.{ }^{*} 2004 \mathrm{~b}: 6 / 2008: 7\right)$ maintains that 'it is in fact a connection of practices, of real practices, that has produced this and leaves its mark on reality'. Although the dispositives have no immediate substantial nature to take hold of, they still affect the actual reality substantially and in various ways. Hence, dispositional analysis does not pretend to be a way of analyzing reality as such. Instead, it is a way of demonstrating how different actions (viewed as prescriptive events) mutually eliminate each other, only to collectively outline a pattern and create a new normative level. Stating the emergence of a new dispositive through a historical transformation amounts to asserting that new guidelines for actions started to 
make themselves known, and not necessarily that the analyzed actions are in perfect accordance with these guidelines. It is not claimed that those who act cause the dispositive to manifest itself directly. As long as one is expounding the dispositive, one is still on the stage of an 'ideality', which remains suspended in 'reality'. The dispositive indicates a systematic, which has had a normative effect on singular programmes that in turn were never implemented as originally intended. Even though the programme of Bentham's Panopticon was never fully implemented in its preconceived form, its modes of operation can still be perceived, but only to the extent that they are rendered intelligible within the larger context of a dispositional arrangement (i.e. the disciplinary dispositive) and its normative influence. The effects of the dispositive are embedded in the institutions and organizations it reshapes. The dispositive is very real in so far as it affects the social reality by installing a most real dispositionality. It may not be an absolute or omnipotent idea; however, as an already implemented ubiquitous set of connections, it is unavoidable for the social interaction to respond to (Foucault *1980: $15-16)$.

An analysis of dispositives does not seek to explain the existence of the major social technologies by referring to the institutions that contain them. Foucault juxtaposes this 'institutionalocentrism' with the endeavour to move 'beyond or outside the institution' 'and replace it with the overall point of the technology of power' ("2004a: 120-121/2007: 116-17). Thus, the analysis of dispositives seeks to unravel how a difficult social exchange, influenced by particular challenges and predicaments, constitutes, runs through, and changes the principal institutions and organizations.

While stressing the necessity of analysing history as a history of dispositives or technological arrangements, Foucault introduces what he calls three basic and particularly important 
'modalities' of dispositives, which he designates 'law', 'discipline', and 'the dispositives of security’ ("2004a: 7-8/2007: 5-6).

Legislation and its outcome, the law, can be construed as a special kind of dispositional arrangement, insofar as it is an attempt to establish a differentiation between the forbidden and the permitted (see Table 1). This legal dispositive exists as a codifying and prohibitive social technology that lays down a binary order, eventually supported by sanctions, to be respected by every legal subject. The law distinguishes sharply between the permitted and the forbidden to specify the unwanted acts. On the other hand, where discipline is concerned, it is a preventive and productive dispositive working to avert the unwanted from occurring and, as such, often fabricating something new as well - something wanted. The disciplinary modality intervenes with the daily existence of its objects being individual bodies, moulding them so that they can be expected to function in a desirable fashion in the future. Just as the law deals with its surrounding world, so does discipline, although now in a prescriptive fashion, aiming to eliminate the unwanted and to prevent it from occurring at all. Conversely, the dispositives of security do not deter; instead, they work conductively aiming to facilitate the selfregulation of a population. The implementation of security precautions is not designed to distinguish between the wanted and the unwanted, nor is it capable of removing or ameliorating the unwanted. Instead, the measures of security establish a readiness to take 'into account that which can happen' (Foucault *2004a: 23/2007: 21), often with reference to its societal utility or inutility (*2004b: 53/2008: 51 ). Thus, this modality of dispositive processes the unexpected in order to avoid potential destructive consequences or, gain from prosperous outcomes.

Foucault emphasizes how the three major dispositives all express distinct dispositional logics and are, at one and the same time, able to share common material. He illustrates this 
important point with a 'childish' example; a simple case of penal law 'you must not steal' (*2004a: 6-8/2007: 4-6). Within the juridical dispositive, theft is treated by 'laying down a law and fixing a punishment for the person who breaks it, which is the system of the legal code with a binary division between the permitted and the prohibited, and a coupling, comprising the code, between a type of prohibited action and a type of punishment' $(* 2004$ : 7/2007: 5). The punishment may, of course, vary significantly from a simple fine, over banishment to severe corporal punishment, or even death penalty. The disciplinary dispositive differs from this form, because it processes theft through a 'series of supervisions, checks, inspections, and varied controls that, even before the thief has stolen, make it possible to identify whether or not he is going to steal' (*2004a: 6/2007: 4). Furthermore, theft is treated post factum by the dispositive of discipline, not only by employing a series of penitentiary techniques, such as obligatory work, moralization, and correction, but also by using a number of investigative, medical, and psychological techniques, which fall 'within the domain of surveillance, diagnosis and the possible transformation of individuals' (ibid.). Within the dispositive of security, the phenomenon of theft is interpreted in yet another manner. It is inserted into a series of probable events and in calculation of costs - 'and instead of a binary division between the permitted and the prohibited, one establishes an average considered as optimal on the one hand, and on the other, a bandwidth of the acceptable that must not be exceeded' (*2004a: 8/2007: 6). More specifically the treatment of theft within the dispositive of security revolves around questions such as:

How can we predict statistically the number of thefts at a given moment, in a given society, in a given town, in the town or in the country, in a given social stratum? [...] What is the comparative cost of the theft and its repression and what is more worthwhile: To tolerate a bit more theft or to tolerate a bit more repression? (Foucault *2004a: 8/2007: 6) 
In sum, statistical prognoses about tendencies of the population, and correspondingly the 'economic' weighing of costs and risks in realizing different courses of action, constitute the dominant framework for dealing with theft within the dispositive of security.

Among these three dispositional modalities, the disciplinary prototype is the most familiar, as it represents the major theme in Foucault's historical account on the birth of the prison. Here, it is not the prison in itself that is Foucault's primary concern. Rather it is a transversal tendency, making it relevant to ask: 'Is it surprising that prisons resemble factories, schools, barracks, hospitals, which all resemble prisons?' ("1975a: 229/1979: 228). The focus of investigation is the complex network that connects and permeates these different institutions as it imbues them with a particular disciplinary dispositionality, which is alterable, transferable, and modifiable, but nonetheless recognizable.

Less famous than discipline, the legal or juridical prototype is mainly dealt with by Foucault in a negative manner, not least in his critique of the conventional understanding of power as being principally sovereign, commanding, prohibitive, and legal in nature (e.g. Foucault *1976/1979; "1997/2003). However, this dispositional modality is also apparent in the various instances where Foucault demonstrates how basic juridical conceptualizations are remolded by the rise of new social dispositions, such as the birth of corrective incarceration in contradistinction to the psychical punishment of sovereignty $(* 1975 / 1979)$, the rise of the reason of state $\left({ }^{*} 2004 \mathrm{a} / 2007\right)$, or the birth of a neo-liberal governmentality in the $20^{\text {th }}$ century ( $2004 \mathrm{~b} / 2008)$.

Likewise, the last prototype of security is more complicated to discern than discipline, as these arrangements seem to correspond to a dispositional halfway house in Foucault's work. On the one hand, they are related to the 'regulatory controls' or the 'biopolitics of the population', which Foucault introduced at the end of The Will to Knowledge as a new social 
order, which was beginning to interact with the 'disciplines' or the 'anatomo-politics of the human body' in the $19^{\text {th }}$ century ("1976: 183/1998: 139). On the other hand, they connect to the seminal notion of 'governmentality', set up by Foucault during his 1978 lectures to give a picture of his analytical enterprise, which was more adequate than the one suggested in Security, Territory, Population (*2004a: 113/2007: 110):

By 'governmentality' I understand the ensemble formed by institutions, procedures, analyses and reflections, calculations, and tactics that allow the exercise of this very specific, albeit very complex, power that has the population as its target, political economy as its major form of knowledge, and dispositives of security as its essential technical instrument (Foucault *2004a: 112/2007: 108-09).

Foucault never systematically explains exactly how the notions of biopolitics, security, and governmentality relate to each other and any schematic representation of his dispositional analysis entails both interpretation and reconstruction. Hence, the table below should not be taken at face value as a true account of all the relevant analytical components, as it not only reduces biopolitics, security, and governmentality into one single societal technology (cf. Dillon and Lobo-Guerrero, 2008), but also pulls together notions, which are not employed by Foucault himself in order to fill out categorical lacunas in the table. Rather, the table aims to illustrate some of the major constituents of the dispositional analysis, by focusing on: (1) the normative order; (2) the exercise of power; (3) the spatiality; (4) the subject position; as well as (5) some of the material Foucault investigates with one particular dispositive in the forefront. 


\begin{tabular}{|c|c|c|c|}
\hline $\begin{array}{l}\text { TABLE 1. } \\
\text { Prototypical } \\
\text { Dispositives }\end{array}$ & LAW & DISCIPLINE & $\begin{array}{l}\text { Biopolitics } \\
\text { SECURITY } \\
\text { Governmentality }\end{array}$ \\
\hline $\begin{array}{l}\text { Normative order } \\
\text { What? }\end{array}$ & $\begin{array}{l}\text { Prohibitive } \\
\text { Forbidden/Permitted } \\
\text { Codifying }\end{array}$ & $\begin{array}{l}\text { Prescriptive } \\
\text { Unwanted/Wanted } \\
\text { "Normating" (Normation) }\end{array}$ & $\begin{array}{l}\text { Conductive } \\
\text { Utile/Inutile } \\
\text { Normalizing }\end{array}$ \\
\hline $\begin{array}{l}\text { Exercise of power } \\
\text { How? }\end{array}$ & $\begin{array}{l}\text { Repressive } \\
\text { Limitation }\end{array}$ & $\begin{array}{l}\text { Productive } \\
\text { Formation }\end{array}$ & $\begin{array}{l}\text { Facilitative } \\
\text { Allowing (laissez-faire) }\end{array}$ \\
\hline $\begin{array}{l}\text { Spatiality } \\
\text { Where? }\end{array}$ & $\begin{array}{l}\text { Territory } \\
\text { State of Law }\end{array}$ & $\begin{array}{l}\text { Localized, analyzed spaces } \\
\text { Institutionalized Society } \\
\text { Le Carcéral }\end{array}$ & $\begin{array}{l}\text { Natural Environment } \\
\text { Civil Society }\end{array}$ \\
\hline $\begin{array}{l}\text { Subject position } \\
\text { Who? }\end{array}$ & $\begin{array}{l}\text { Legal Subjects } \\
\text { Codifying acts }\end{array}$ & $\begin{array}{l}\text { Individual Bodies } \\
\text { Controlling behaviour }\end{array}$ & $\begin{array}{l}\text { Population } \\
\text { Conducting conduct }\end{array}$ \\
\hline $\begin{array}{l}\text { Selected material } \\
\text { from Foucault's } \\
\text { work }\end{array}$ & $\begin{array}{l}\text { Law, Jurisprudence, Classical } \\
\text { political philosophy, Internment, } \\
\text { Representation, Public } \\
\text { punishment, Sovereignty, } \\
\text { Confinement of madness }\end{array}$ & $\begin{array}{l}\text { Asylum, Administrative } \\
\text { institutions, Bad consciousness, } \\
\text { Crime rates, Criminology, } \\
\text { Educative imprisonment, } \\
\text { Examination, Forensic } \\
\text { psychiatry, Military parade, } \\
\text { Psychology, Pedagogy, Prisons, } \\
\text { Surveillance, Schools, } \\
\text { Workshops }\end{array}$ & $\begin{array}{l}\text { Liberal art of government, } \\
\text { Neoliberalism, Political } \\
\text { economy, Statistics, Pastoral } \\
\text { power, Raison d'état, Human } \\
\text { Capital }\end{array}$ \\
\hline
\end{tabular}

On the contrary, Foucault points out how different modalities of dispositives can co-exist and even presuppose each other:

It is absolutely clear that in the juridico-legal system [...] the disciplinary aspect [was] far from absent since, after all, when a so called exemplary punishment was imposed on an action, [...] it was in fact precisely with the aim of having a 'corrective effect'. [...] We could [say] the same with regard to the disciplinary system which includes a whole series of dimensions that absolutely belong to the domain of security. Basically, when one undertakes to correct a prisoner, [...] one tries to correct the person according to the risk of relapse, that is to say according to what will very soon be called his 'dangerousness' - that is to say, again, a mechanism of security (Foucault *2004a: 9/2007: 7). 
In retrospect, other considerations besides that of the law were already present and imperative in order for the law to function. The practice of the law already had an implicit disciplinary and securing effect. Meanwhile, such implicit matters may turn out to be a primary matter for other dispositives. The secondary disciplinary effect of the law has a better chance of succeeding if special disciplinary dispositives are established with the specific purpose of correcting.

In conclusion, all this amounts to the proposition that within a specific type of dispositive, certain aspects of social interaction will be displayed, manifesting themselves as unavoidable matters to relate to, all the while the given dispositive is itself influenced by other dispositives. Thus, the history of dispositives is the story of how rudimentary considerations are articulated in a fundamentally endless movement. Our modes of existence are differentiated into relatively self-dependent types of social interplay that increasingly separate from each other without ceasing to interact with other dispositives in respect to empirical phenomena or experiences.

\section{Implications of dispositional analytics}

Foucault's notion of the dispositive contributes to the study of organization and management through more complex understanding of organizational dynamics. It leads the way beyond established dichotomies that continue to leave an overly simplified reductive picture of organizational life, despite scholars' professed and sincere wish to avoid such dualities. The remaining part of the article will demonstrate this in relation to six major themes: (1) As dispositional analysis circumvents the division between the discursive and the non-discursive, it permits us to move beyond discourse analysis and a tendency to reduce organizations to discursive constructions, ordered by the transcendental workings of language. (2) As it 
repudiates sharp-cut, general periodizations, dispositional analysis resists a univocal analysis of organizational life in terms of an 'x-society' and permits the articulation of complex and multidimensional overdeterminations. (3) Questioning an either-or of power and freedom, and between determinism and agency, dispositional analysis opposes received conceptions of strategy as planning and deliberate forethought and renders a concrete, non-deterministic analysis of power-relations and strategy possible. (4) Avoiding a commonly perceived dichotomy between the organization as a regime producing compliance and resistance conceived as opposition, dispositional analysis permits the detection of immanent tendencies to resist and articulate how they contribute to shaping organizational order and making it dynamic, but also fragile and precarious. (5) Eschewing clear-cut distinctions between prevailing practices and an oppositional theoretical critic arriving in the organization from the outside, between existing and alternative norms, dispositional analysis substantiates critique as an immanent activity that affirms and further articulates an already ongoing prescriptive activity. (6) So doing, dispositional analysis draws our attention to a new level of existence as crucial for organizing: the virtual. This forces organization studies to go outside what used to be its foundational object and defining feature.

\section{Beyond discourse analysis and the dichotomy between discursive and the non-discursive}

Since the difference between the linguistic and the non-linguistic does not attain the status of a fundamental divide within dispositional analytics, this approach runs counter to the 'linguistic turn' and its decisive impact on the social sciences since the 1980s (Alvesson and Kärreman 2010; Fairclough 2010). This turn has 'made discourse analysis an increasingly important element for organization studies' (Leclercq-Vandelannoitte 2011: 1247) and purports to show how discourses and communication play a particularly decisive role in 
organizations as they constitute, produce, and mediate organizational phenomena, or even directly shape reality. Distinguished scholars within organizational research even adduce Foucault an alleged crucial instigator of this linguistic turn and claim his 'methodology' permits us to understand corporate strategy and organizing as 'a discourse', or as 'a set of ideas and practices conditioning the ways we relate to and act upon particular phenomena (Knights and Morgan, 1991: 251, 253). Evading a tendency to focus on the key role of language in constituting organizations (Deetz, 1992; Cooren), the dispositive allows us to move beyond this transcendental approach to language that threatens to reduce organizations to discursive constructions and organizing to linguistic practice. By contrast, the dispositive maps a systematism that cuts across and closely connects the discursive and the nondiscursive. Without reducing one to the other, the dispositive permits a concrete analysis of the interchange between the linguistic and the common dispositions that come to the fore within both domains and tie them together.

That the inter-relationship between the discursive and the non-discursive is of paramount importance for organizational analysis becomes apparent when one of the 'Big Four' worldwide accounting and consultancy firms introduces their new employees to company core values only to confront them with a film indicating that most regular employees are unable to even name even one of the basic stated norms, while still depicting them as a very important contributions to the organization (Presskorn-Thygesen 2012: 6-8).

The point of indicating this mutual irreducibility is not to show that the imposition of corporate values fosters a cynical distance from employees in order to save their 'authentic' selves (Kunda, 2006). Neither does management simply seek to reincorporate such cynicism by prescribing the new norm 'just be yourself' (Flemming and Sturdy 2009). In these approaches, the discursive and the communicative levels are basically conceived as the active 
transcendental level where an organizational reality is constituted such that organizational behaviour must react and respond to it.

By monitoring the film, management shows that it is insufficient to confine oneself to understanding the discourse of the company's stated values to grasp the workings of the organization. One must also include a broader range of organizational practices. Here normativity emerges as an essential, irreducible part of the understanding. An analysis of the company's basic stated or communicated norms together with an examination of how employees respond and react to these norms gives a very limited and thus distorted picture of organizational behaviour and the norms that the organization actually adheres to. It also ends up giving a very reductive and reactive representation of organizational interaction and selfrelations as oppositional and reactive. This is because it tends to ignore the ways in which binding norms are actively created in new and agenda-setting ways. The case thus shows that one must examine the norms stated as well as the normativity emerging in what is done. Also, the relationship between them must be taken up to get a more comprehensive picture of the normativity guiding and conditioning organizational practice. This is what the 'both-and' of dispositional analysis permits to do in contradistinction to discourse analysis, insofar as the latter takes the dichotomy between the discoursive and the non-discoursive as its starting point.

Not only in this manner does dispositional analysis seek give a more comprehensive and nonreductive picture of organizational life. It equally gives a more complex and nondeterminative analysis of organizational ordering in other respects.

\section{From discontinuous periodization to complex constellations}


When dispositional analysis repudiates the well-defined periodizations strongly associated with Deleuze's reading of the dispositive, and particularly his proposal as to the 'Societies of Control', our approach also challenges a common propensity in organizational research to separate the present (or an earlier) historical state from what has been the case hitherto. Particularly, this has been the case when the world and reality of organizations, from a certain moment in time, is diagnosed as reproducing a 'disciplinary society' and an 'institutional framework of incarceration' (Burell, 1988: 111-12; cf. also Townley 1998, 191-210). Or when notable scholars (Carter et al., 2002; Knights 2002) have urged us to move beyond the disciplinary horizon, because a new kind of world and existence has dawned, making the conventional analysis of discipline miss its target (Weiskopf and Loacker, 2006; Weiskopf and Munro, 2011).

Organizational theory that begins by establishing (a series of) epochal dichotomies, drawing a clear dividing line between 'before' and 'after', risks adopting a simplistic approach to concrete organizational analysis. It tends to be on the lookout for a simple unifying and allpervading trait, distinguishing and characterizing a given epoch or societal state. Also it tends to find it confirmed as a normativity domineering concrete organizational practice.

By contrast, the dispositional analysis is keen to avoid any use of epochal characterizations, let alone describe historical development as successive epochs replacing each other in a 'kind of historical schema' (Foucault, *2004a: 8/2007: 6). In fact, investigations in the 1978 lectures, where he develops the notion of dispositive in concrete terms, functions as a way of distancing himself from an epochal interpretation of discipline in terms of a 'generalized disciplinary society' (*1997: 225/2003: 253; *2003: 68/2006: 66; *1975: 217/1979: 216). Crucially, this also rules out other epochal 'candidates' in terms of security, population, risk, control, post-discipline etc. In general, it is the very idea of epochal characterizations, 
reiterated in organizational studies that is questioned by dispositional analysis. The task of the analyst cannot be to suggest that we have entered, or are on the brink of a new era characterized by a novel form of social rationality. Such prophetic or eschatological brinkmanship is disavowed in an analysis that brings out the 'shift of emphasis' rather than the 'substitution' (Foucault, *2004a: 373/2007: 363).

On the one hand, the proposed dispositional analysis is therefore readily in accordance with Weiskopf and Munro 2011: 688-89) when they distinguish a disciplinary apparatus, 'centripetally' working on the human body through isolation of space, meticulous concentration or enclosure, and a security apparatus 'centrifugally' dealing with human conduct by expanding and integrating new elements into circulation; between what is essentially prescriptive and obliging, and what stimulates social reality to act upon itself in order to cancel out what may endanger the population. On the other hand, the dispositional approach problematizes an organizational analysis that claims to leave 'the old, "sovereign power"" or the legal dispositive behind, as if it only belonged to an extinct society. Characterizations of 'the disciplinary mode of organizing power over life' as something that was not only 'gradually complimented', but also 'supplanted by apparatuses of control' (Weiskopf and Munro, 2011: 686-687), risks becoming equally declarational and thus oversimplifies the analysis of actual organizational life.

Working along these lines, dispositional analysis resists a univocal description of the interactions in the social field in terms of an 'x-society'. Though often asserted by Foucauldian scholars in organizational studies, an alleged shift to an all-encompassing disciplinary society or a change from a disciplinary society to a society of control amount to proclamations and analytic simplifications that obstruct proper empirical investigation. 
With dispositional analysis, an analytic account of organizations that tends to fall prey to a relatively simple 'either-or', cedes to an approach that articulates institutional practice in terms of several contending 'both-ands'. Prescriptive codification may still be very present in organizational life, but perhaps this is precisely because it permits staging processes of disciplinarization. Conversely, disciplinary measures may well serve processes of selfregulation. A simple analytic explanation of organizational behavior in terms of a single alldetermining logic is here supplanted by and reincorporated within an articulation of organizational practice through an agon between different kinds of normative activity, which do not mutually exclude one another, but instead compete with, challenge, affect, modulate, and at times reinforce each other. From the vantage point of dispositional analysis, organizational practice stands forth as a complex, multidimensional and overdetermined field to be articulated. Here various kinds of pervading, yet not all-powerful, dispositional logics come into play and concur to create a multi-layered field of normativity (see Table 1 above). The introductory course mentioned above may be read as indicating organizational dependence on this multi-layeredness and as recognizing the urge to make it visible. The agon also affects the understanding of intentionality, strategy, and power.

\section{From intentional strategy to the potency of indirect action}

On the face of it, a transparent logic seems to be present when individuals act with specific intentions. At this stage, different problems present themselves and call for solutions to the difficulties at hand. Those who act, relate to former actions and may attempt to take potential responses into account. Each action and each related intention are intersected by other actions; and because of this interaction, the result is never fully pre-determined. A new regularity 
appears (Foucault, *1984) in this interplay between actions, and a new pattern emerges amidst the actions and their intentions. This pattern is the dispositive.

Accordingly, the dispositive is not to be understood as the elimination of intentionality, will, and freedom, but rather as a result of an abundance of intentions at play that cross and interact to create a pattern that exerts a decisive influence on later initiatives, but exactly without ruling out and eliminating the influence of intentionality, will, and freedom. At the very heart of the dispositive, constantly evoking, provoking, and developing it, we paradoxically find precisely 'the re-calcitrance of the will and the intransigence of freedom' (Foucault, 1982: 221-22).

In this manner, the dispositive does not rule out, but indeed presumes the existence of intentionality and strategic initiatives as actions that contribute actively to shaping the dispositive and the organization. Insofar as 'strategy' is 'conceived in terms of what the leaders of an organization "plan" to do in the future', and 'strategy formation' as 'an analytic process for establishing long-range goals and action plans for an organization' (Mintzberg and Waters, 1985: 257), such 'deliberate forethought', as designated by Chia and Holt (2009: ix), is here perceived as having significant effects on organizational life. The effects of purposefulness and design are only lasting, however, to the extent that they are able to enter into interaction with, and affect wider organizational contexts beyond their control (Raffnsøe 2013; Raffnsøe et al., 2014), as is also evident in the case of the accounting firm. From this perspective, the dispositive could also be conceived as 'a mode of comprehension' (Chia and Holt, 2009: xi), or a diagnostic tool that permits us to grasp 'emergent strategies' (Mintzberg, 1994: 25) as they are realized, traversed, and leave their mark on the organization, even though the realized strategic pattern may not have been expressly intended 
by anyone, but comes into existence as the result of an ongoing interaction and stays subject to further modification.

The dispositive allows the analyst to access the very level of existence where mutual prescription emerges as a result of, and transcending intentional and strategic interaction. This diagnostic tool permits a concrete, not otherwise possible, empirical analysis of mutual guidelines as they become established in and leave an indelible mark on interaction, but without eradicating freedom and human will. This level of analysis permits us to articulate an ongoing conditioning of human agency within a certain field that results from, affects, and includes agency and freedom, will, and intentionality.

Comprehending deliberate strategic intent as a contribution to a larger emergent field out of which a realized coordinated strategic action eventually arises, the dispositional analysis also problematizes a conception of strategic management as a creature of the human will aiming at ‘long range planning' (Cummings and Daellenbach, 2009: 234). This conception was, to a great extent, inherited from modern European warfare and military theory (Cummings, 2002), which defined strategy as 'the science of military and warlike movements beyond visual and gunshot range' (Bülow, 1805: 83-84). Instead of subscribing to modernity's notions of strategy and management that places them above and at the fringes of organizational life, dispositional analysis makes a case for understanding it as a process of 'wayfinding' (Chia and Holt, 2009). As the outcome of entering into social interaction, this process of wayfinding would be in accordance with early Greek conceptions of the strategoi as a strategic leader who was expected both to direct and take part in the battle (Cummings 1993).

Along these lines, the dispositive renders a concrete, non-deterministic analytics of powerrelations possible. The dispositive has the capacity to affect someone or something in ways that effect or bring about certain outcomes or at least make them more likely (Raffnsøe 2013: 
248). It allows us to circumvene a received notion of power as an ability to express one's will and get one's way, which is closely associated with command, coercion, control and calculation (Raffnsøe 2013). This has determined the exercise and understanding of power in Western societies, as it has formed its institutions and organizations and the conception of sovereignty (Raffnsøe, 2002; Raffnsøe, 1996).

Surpassing this relatively simple conception of 'power over' (Morriss, 1987; Haugaard, 2012a; Pansardi, 2012), power as rule, and domination of an entity, the dispositive permits us to analyze more subtle forms of power that traverse the organization and must be theorized as 'power to' (Barnes, 1988; Allen, 1999; Haugaard, 2012; Morriss, 1987; Pansardi, 2012; Morriss, 2012). This 'power to' is power understood as the ability to affect others in ways that influence their dispositions, meaning their ability and tendency to unfold themselves as they behave and act in specific ways. It is power analyzed as a 'mode of action upon actions' (Foucault, 1982: 220), as a capability to 'conduct conduct (conduire des conduites)' (Foucault, *1984b: 315), and thus power as closely associated with the exercise and the management of freedom (Foucault, 1982: 221). It is also power conceived as a relational and pluri-directional capability to affect the dispositions within a social field, not only the dispositions of others, but also our own (Raffnsøe 2013).

As a result, the dispositive permits a 'heightened awareness of the surprising efficacy of indirect action' and permits us to diagnose the 'dramatic and lasting effects' resulting from this kind of power (Chia and Holt 2009: x, 2). When coming into being, as actors act upon the action of others, the conception of power as relational and pluri-directional questions the idea of strategy as initiatives taken by management situated over and above the organization, which are simply to be implemented by it. It also questions a traditional unilateral notion of agency and makes room for a more complex understanding. 
Not only do initiatives taken by leaders and managers become deflected as soon as they begin to interact with other initiatives. Moreover, new patterns are created through the interaction, which must be analyzed at the level of the dispositive. In this way, the dispositional logic also accounts for difficulties in creating and maintaining a potent order of control in organisations. From the perspective of those 'originally' in power, there is always the risk that others do not obey and that initiatives will prove impotent. In return, there is also the chance that what happens will create a mediated potency and agency beyond their control (Raffnsøe 2013). This is likely if the strategist proves capable to act in ways that not only constrain, but also facilitate the actions of others, and if he/she takes the dispositives that he/she contributes to articulate into due account. As a construct affecting existing and creating new dispositions, this agency and potency can be analyzed at the level of the dispositive.

\section{From reactive resistance to active insistence as a condition of possibility for organizing}

Examining the dynamic interaction between various types of dispositives, dispositional analytics thus allows for a diverse and multifaceted analysis of present organizational life. This differs from a simplified picture of organizations that the described dichotomies tend to result in. At the same time, however, the dispositive indicates - and is able to account for - the dynamics inherent in forms of organizing: their productivity, their inclusiveness and force of attraction, their diversification and dissemination. This is due to the circumstance emphasized earlier that the intransivity and irreducibility of freedom, as well as the insubmissivenes and unmanageability of the will are at the very heart of the dispositive (Foucault *1984b: 315). Analyzed at the level of the dispositive, freedom comes first, since it is to be recognized as an always already existent part and driver of internal, organizational dynamics and differentiation. Thus, freedom and insubmissiveness should be reckoned with as irreducible 
conditions of possibility that allow and are already incorporated into organisational dynamics, as well as personal conduct (Raffnsøe et al., 2014).

One fails to live up to this Foucauldian notion of freedom if one conceives freedom as resistance, or as a response to an opposition of and thus, to some extent, also a mere consequence of an already established organizational practice. Yet, often, leading organizational scholars tend to establish a fundamental dichotomy between an understanding of the organization as a uniform entity and a resulting resistance (Smith 2008; Mumby 2005), responding to an opposing existing institutional practice. In organization studies, 'talking about resistance largely means addressing the processes through which a taken for granted phenomenon (for instance managerial hegemony) is more or less suddenly unveiled (...) and made questionable' (Courpasson and Dany 2013: 332). Here resistance is conceived as 'resistance against' and as 'counter-hegemonic, collective struggles' where employees 'resist the colonization of their subjectivity through outright rejection' (Spicer and Böhm 2007: $1667,1668,1670)$.

This conception of resistance is also prevalent within Foucauldian organization scholarship. The pervasiveness of the notion of resistance may be the outcome of the described predilection for Foucault's earlier works in Foucauldian organization scholarship, since Foucault's analysis of law and discipline - as conceived here - suggests a relatively simplistic conception of organizational life and resistance. The preference for Foucault's early work, its 'transgressive Kitsch', 'confuse demand to be radically different (konfuse Verlangen nach totaler Andersheit)' (Sloterdijk 2009: 240-41) and its ensuing preoccupation with resistance may in turn arise from leading Foucauldian organization scholars' origin in, or intimate relationship to, earlier forms of critical theory. In connection with the discussed tendency to distinguish between supplanting epochs, and to privilege Foucault's writings on discipline, 
even when scholars strive to discern the distinguishing trait of the modern organization (Burrell, 1988; Knights, 2002; Knights and Morgan, 1991), the dichotomy often entails that the order of organizational life tends to be understood as a regime that manages, controls and 'produces submission and compliance' (Jackson and Carter 1998: 60) and thus as an exercise of power basically opposed to and restraining the realm of freedom. Accordingly, 'Foucauldian-influenced studies have been criticized for being too deterministic and totalizing, focusing on subjectification as subjection' (Thomas and Davies 2005: 686). In this case, employees seem to face the dualistic alternative of "compliance with" versus "resistance to"" (Thomas and Davies 2005, 683-706: 683), or the prospect of becoming an automaton (Smith 2008) implementing what is already given lest they revolt; and even in this case may they succumb, as the identity of the employee and the citizen is essentially forged by and subjugated in the modern technologies and dispositives of power (Knights and Willmott, 1989). When resistance remains 'locked within a negative paradigm' and is seen as a reactive 'response to repressive power' (Thomas and Davies 2005: 687), one ends up falling prey to a primarily negative conception of power as restraint. This links up with a conception of freedom as the ability to liberate oneself from such imposed constraints. This dualistic approach differs from Foucault's account of a mutually intensifying and productive relationship between power and freedom. Moreover, the 'repressive hypothesis' (Foucault 1976) leads to a rather undifferented and negative picture concerning the virtues (and vices) of organizing, which is unable to account for its dynamism and variability, inclusiveness and attractiveness.

To the extent one speaks of freedom in terms of resistance against and as a result of hegemony, subjugation, and oppression, it is doomed to remain a primordially indescribable phenomenon outside the established order. To remedy this defect, because of an alleged bias 
in the reception of Foucault so far, a number of scholars have argued the necessity of introducing hitherto neglected aspects of his work. Particularly the later studies concerning technologies and practices of the self have been employed to address the role of subjectivity and the possibility of agency and resistance in organizations (Newton, 1998; Barratt, 2008; Katarzyna and McKernan, 2011; Townley, 1994; Townley, 1995a).

Contrary to professed intentions to "provide a basis by which to consider resistance, struggle and change' (Newton, 1998: 416) and theorizing and treating the hitherto underprivileged subjectivity by circumventing established dualisms and essentialism (Knights and Willmott, 1989), these efforts threaten to remain a compensatory exercise as long as subjectivity is primarily conceived as a subsequent and reactive element. Moreover, power conceived as domination, control, and subjection and in extension resistance perceived as freedom and subjectification still seem to oppose one another as belonging to basically contrasting fields or realms that mutually exclude each other.

As a consequence, even the literature that subsequently pursues 'an increasing interest in the active role that the human subject plays in his or her own subordination, self-creation and self-fashioning' (Barratt, 2008: 516) seems unable to bridge the gap. On the one hand, the unitary workings of a 'historical mode of being' seem to pervade the organization. On the other hand, an attentiveness to the 'possibilities of human autonomy' (Barratt, 2008: 518) is deemed necessary to oppose the experienced ontology. At a theoretical and analytical level, however, these poles threaten to remain separate worlds as long as freedom in the guise of resistance is only allowed to follow, as a (possibly creative) reaction to existing institutions, and not to precede as an ongoing active driver in organizing.

By contrast, the notion of dispositives was introduced by Foucault as an analytic device to circumvent a dualistic approach to social organizing and 'replace' a predominantly repressive 
understanding of human organizing within a 'general economy' (*1976: 19/1998: 11; translation altered). From the vantage point of a larger multiplicating, proliferating, inciting, and penetrating logic of power and subjectification, 'forbidding' and 'censoring' 'might well be only secondary devices (dispositifs seconds)' (*Foucault 1976: 30; Foucault, 1998: 21, translation altered) that serve an active role within the role of a larger dynamic.

Consequently, the first remarks of Foucault's 1978 lectures (*2004a: 3-4/2007: 1-2) frame his ensuing history of dispositives as an analysis of procedures and technologies of power, in which power and resistance cannot be separated. A dispositional logic interacts dynamically with its surroundings in a way that modifies its normativity, wherefore it is under 'permanent modulation' (Weiskopf and Loaker, 2006: 402) and contains an intrinsic tendency towards 'self-modification'. Indeed, Foucault stresses this point in relation to the dispositive of security by speaking of an 'immediate and founding correlation between conduct and counterconduct' (*2004a: 199/2007: 196; cf. Davidson, 2009). Thus, freedom in the form of an ongoing 'dis-institutionalization' and self-modification is an inherent part of dispositives. According to a dispositional approach, resistance is not to be conceived as an oppositional reaction, but rather as an already active and transgressive force rendering organizational order feasible and dynamic, but also provisional, precarious, and modifiable.

Accordingly, critique is also to be recognized as an already existent, vital part and driver of organizing, not as an unfamiliar activity arriving in and affecting the organization from the outside.

\section{Critique is affirmative, immanent and transcendatory}

The perception of the organization as dominated by the unitary workings of a historical mode of being and the correlating conception of resistance as an oppositional exception to otherwise 
hegemonic rule, places the critic of organizational life in an exposed and delicate, yet very crucial position. As demonstrated by Foucault around the time when he forged the notion of the dispositive, this 'repressive hypothesis' of the workings of power with its allied monolithic conception of social order has the merit that it gives the analyst 'the speaker's benefit': If something 'is repressed, that is, condemned to prohibition, nonexistence, and silence, then the mere fact that one is speaking about it has the appearance of a deliberate transgression. A person who holds forth in such language places himself to a certain extent outside the reach of power, he upsets established law; he somehow anticipates the coming freedom. (...) Something that smacks of revolt (...) of the coming age of a different law' (Foucault 1998: 6-7).

Initially, assuming a marginal position as someone who arrives in the organization from the outside, the critic of management and organization occupies the centre as a 'frank speaker' (*2008/2010), confronting the organization with upsetting truths that shake established hierarchies and speaks of a world beyond them (Townley, 1995b; Chan and Garrick, 2002; Wray-Bliss, 2002). As Critical Management Theory 'challenges prevailing relations of domination (...) and anticipates the development of alternatives, it habitually begins by the either-or of a negative critical 'against' (or for) and a divide between prevailing practice and a oppositional 'study of' it, adhering to different norms (Alvesson et al., 2009: 1). 'At times', Barrat writes, 'it is as if critique might somehow transcend power relations' (2008: 531). By contrast, dispositional analytics seeks to characterize the general tendencies within the field of real forces. The very notion of dispositionality is designed to eschew a clear-cut distinction between the factual and the normative, power and freedom, as it focuses on how normativity is already beforehand established and at work in the social field - often at a prereflective level. Hence, critique does not need to induce normativity standards into the 
analysis in order to attain a critical level of reflection, but can rather affirm implicit and yet overlooked tendencies already becoming established in the social interactions by highlighting them in the analysis. This to elucidate their normative content and explore where it might lead us and how it might affect us (Raffnsøe 2014).

Particularly perceptible in his predilection for a hyperbolic articulation of the logic at work, Foucault's critical affirmative stance leaves its mark on his analysis of the dispositives of law, discipline and welfare/security. Yet, his conception of critique is also strikingly present in his approach to neo-liberalism (Raffnsøe, Gudmand-Høyer, Thaning 2015, chapter 13), often opposed as a hegemonic discourse or ideology in organizational and critical management studies (Hassard et al., 2001; Fournier and Grey 2000). According to Foucault's critical attitude, however, liberalism is neither to be approached as 'an ideal' that one should devote oneself to, nor as 'an ideology' that can simply be exposed and opposed (*2004: 50/2007: 48). Instead of situating himself as either a proponent or a critic of liberalism, Foucault adopts a diagnostic approach, as he investigates it as 'an element' of a 'form of government and a government "rationality" of very high complexity' (ibid). This is done to piece together how various parts of its logic form an overall pattern. Foucault investigates a knowledge and art of government that already seems to have grown under our skin and become an momentous integral aspect of our present everyday working and private lives, whether on the margins or at the center of the social order. By doing so, his ambition is to examine how and to what extent this discursive and non-discursive practice sets a new agenda and exerts a decisive and equivocal influence that we are still in the process of discovering. Already in his preliminary remarks concerning the methodology of dispositional analysis, Foucault distances himself explicitly from a widespread 'theoretical or analytical discourse' that conceives critique a general response to a predominant force, and thus positions critique 
as an initially negative act, originating in passivity and reactivity, by describing it as a both aesthetic and moralizing, but ultimately gratuitous discourse:

In the theoretical domain, the imperative discourse that consists in saying 'love this, hate that, this is good, that is bad, be for this, beware of that', seems to me (...) to be no more than an aesthetic discourse that can only be based on choices of an aesthetic order. And the imperative discourse that consists in saying 'strike against this and do so in this way', seems to me to be very flimsy when delivered from a teaching institution or even just on a piece of paper (Foucault, *2004a: 5/2007: 3).

With dispositional analysis, critique thus takes on a positive and affirmative character. The aim is not a negative effort to distance oneself from our surroundings by identifying mistakes and limitations. Instead, critique first centers upon an effort to articulate something that is taken to be decisive and agenda-setting for social organization and then takes the form of a pragmatic and practical examination of what we are in the process of becoming and can become as humans. Indeed, this is done with an outset in given dispositions that affect us (Raffnsøe, 2015, forthcoming). Critical distinction and judgment do not function as a theoretical and distant determination of an object or a practice that is assessed and rejected from a moral vantage point beyond the assessed. As Foucault demonstrated with his critical affirmative stance to neo-liberalism, critique can be an unprejudiced judgment that takes what is to be assessed as its starting point to determine what is at stake and where it might lead. Critique takes an outset in a rupture in the examined field in order to confirm this movement. In force of actively escorting this, often ambiguous, movement actively on its way and examining where it might lead us in the extreme, critique affirms this movement, but only to transcend it from within.

In this sense, dispositional analysis is an affirmative critique of possible relevance for organizational scholars, insofar as they seek to redevelop their critical practice and avoid 
repetitive analysis that oscillates 'between determinism and counteraction', rather than 'opening the space for something new' (Caldwell, 2007: 779; cf. Parker and Thomas, 2011).

\section{A new transversal and transgressive object for organizational analysis}

At the most basic level, dispositional analysis draws our attention to a new level of existence, which is crucial for organizing, as it focuses on a 'contemporaneousness' (Deleuze and Guattari 1988: 164), which plays a 'piloting role' in guiding potential interactions with ourselves and others' (Butler, Jeanes, and Otto 2014, 167-175: 2). Instead of focusing on either the established social order of the factual or the utopian state of the counterfactual, an imagined and anticipated contrast, organization studies could gain from detecting an 'intermediate' level that is easily overlooked in organizational theory, even though it seems to have gained increasing importance and attention in organizational life (Raffnsøe and Staunæs, 2014). This is the future as it is always already arriving in the process of an ongoing transformation of the present and the past, in which reality is reconfigured and our capacity and dispositions to act are modified. Instead of confining ourselves to paying attention to either the actual and what is the case or the counterfactual that we may anticipate or hope for or fear, dispositional analysis permits us to articulate another very real and momentous aspect of the world: the virtual (Deleuze, 1996; Deleuze 1988; Raffnsøe 2013). The virtual is not simply to be conceived of as the possible, but as a level of existence that is already operative in the present as a force (virtus), making itself felt as something that acts in and through the given (Leibniz, 1898: 26-27). As a critical performativity eschewing a dialectics of control and resistance (Alvesson et al., 2012; Spicer et al., 2009), the level of the virtual is continually effective in and through what is observable, as it causes the present to transcend itself and 
unfold in certain determinate directions that disposes us to act, think, anticipate and experiment in certain new ways, calling for further exploration.

This dispositionally prescriptive level is a crucial aspect of social reality in organizational life, since it has a determining effect on what is taken for granted and considered real.

Furthermore, it determines not only what is and can be considered possible, but also what can even be imagined and anticipated as potentially realizable, as something one can hope for, or act to bring about (Raffnsøe, 2006: 4-5). Since the prescriptive dispositional level has always already played a guiding role in shaping organizational life, it gains analytical and ontological precedence over the actual and can in this sense be regarded as more important than the present organizational order.

Dispositional analysis forcefully demonstrates the need to resituate and re-evaluate strategic initiatives, be they taken by senior management or employees. This is not only the case within the silent efficacy of indirect action in general, but within the more specific efficacy of various already emerging dispositional strategies controlled by no one that traverse the organization, and deflect strategic initiatives from their intended target, if they are not heeded properly. No other approach to organizational analysis permits us to grasp the dispositional and virtual level as level of existence constitutive for organizing. As an 'outside coming in' (Massumi, 2002: 135), the virtual orderings of dispositives also demonstrates the need for management and organizational theory to go outside the organization as a self-contained demarcated entity of intervention and field of investigation. As the outside presents itself as an obligation to be met and an activity to be undertaken inside the organization, the organization as a demarcated entity is undermined to the extent that what used to be organization studies' foundational object and defining feature is problematized (Lopdrup-Hjorth, 2013). By challenging traditional organizational theory in this manner, 
however, dispositional analysis opens the prospect that organization studies may stay an active and animated discipline whose 'selling proposition' is its ability 'to disagree', also and in particular with itself (Parker and Thomas, 2011: 425-26).

\section{Acknowledgements}

The authors would like to thank the editor of Organization, Professor Robyn Thomas and three anonymous reviewers for scrupulous readings and most perspicacious remarks. Their comments have contributed significantly to improving the article. Thank you also to Thomas Robinson and Mathias Adam Munch for competent language assistance.

\section{References}

Agamben, G. (2009) What is an Apparatus? and Other Essays. Stanford: Stanford University Press.

Ahonen, P. and Tienari, J. (2009) 'United in diversity? Disciplinary normalization in an EU project', Organization 16(5): 655-679.

Al-Amoudi, I. (2007) 'Redrawing Foucault's Social Ontology’, Organization 14(4): 543-563.

Allen, A. (1998) 'Rethinking Power', Hypatia 13(1): 21-40.

Allen, A. (1999) The Power of Feminist Theory : Domination, Resistance, Solidarity. Boulder, CO: Westview Press.

Althusser, L. (1970) 'Idéologie et appareils idéologiques d'État', in Althusser, L. (1976) Positions (1964-1975). Paris: Les éditions socials: 67-125.

Alvesson, M. and Kärreman, D. (2010) 'Varieties of Discourse: On the Study of Organizations through Discourse Analysis', in SAGE Directions in Organization Studies, edited by S.R. Clegg. Vol. 2, 331-252. London: SAGE. 
Alvesson, M. and Spicer, A. (2012) 'Critical Leadership Studies: The Case for Critical Performativity', Human Relations 65(3): 367-390.

Alvesson, M., Bridgman, T. and Willmott, H. (2009) 'Chapter 1. Introduction', in The Oxford Handbook of Critical Management Studies, edited by M. Alvesson, T. Bridgman and H. Willmott, 1-26. Oxford; New York: Oxford University Press.

Aradau, C. and van Munster, R. (2007) 'Governing terrorism through risk: Taking precautions, (un)knowing the future', European Journal of International Relations, 13(1): 89-115.

Bardon, T. and Josserand, E. (2011) 'A Nietzschean reading of Foucauldian thinking: Constructing a project of the self within an ontology of becoming', Organization Organization 18(4): 497-515.

Barnes, B. (1988) The Nature of Power. Urbana: University of Illinois Press.

Barratt, E. (2008) 'The later Foucault in organization and management studies', Human Relations 61(4): 515-537.

Bell V. (2006) 'Performative Knowledge', Theory, Culture and Society 23: 214-17.

Bührmann, A. D. and Schneider, W. (2008) Vom Diskurs zum Dispositiv. Eine Einführung in die Dispositivanalyse. Bielefeld: Transcript Verlag.

Bülow, H. D. von. (1805) Lehrsätze Des Neuern Krieges : Oder Reine Und Angewandte Strategie Aus Dem Geist Des Neuern Kriegssystems. Berlin: Frölich.

Burrell, G. (1988) 'Modernism, Post Modernism and Organizational Analysis 2: The Contribution of Michel Foucault', Organization Studies 9(2): 221-235.

Bussolini J. (2010) 'What is a Dispositive?', Foucault Studies 10: 85-107.

Butler, N. and Dunne, S. (2012) 'Duelling with dualisms: Descartes, Foucault and the history of organizational limits', Management and Organizational History 7(1): 31-44. 
Butler, N., Jeanes, E. and Otto, B. (2014) 'Diagrammatics of Organization', Ephemera 14(2): 167-175.

Caborn, J, (2007) 'On the Methodology of Dispositive Analysis', Critical Approaches to Discourse Analysis Across Disciplines 1(1): 115-23.

Caldwell, R. (2007) ‘Agency and Change: Re-evaluating Foucault's Legacy’, Organization 14(6): 769-791.

Callon. M. and Muniesa, F. (2003) 'Les marchés économiques comme dispositifs collectifs de calcul', Réseaux 6(122): 189-233.

Carter, C. (2008) 'A Curiously British Story: Foucault Goes to Business School', International Studies of Management and Organization 38(1): 13-29.

Carter, C. and Rowlinson, M. (2002) 'Foucault and History in Organization Studies', Organization 9(4): 527-547.

Carter, C., McKinlay, A. and Rowlinson, M. (2002) 'Introduction: Foucault, Management and History', Organization 9(4): 515-526.

Carter, P. and Jackson, N. (1998) 'Labour as Dressage', in McKinlay, A. and Starkey, K. (eds) Foucault, Management and Organization Theory. London: Sage Publications: 49-64.

Chan, A. and Clegg, S. (2002) 'History, Culture and Organization Studies', Culture and Organization 8,(4): 259-273.

Chan, A. and Garrick, J. (2002) 'Organization Theory in Turbulent Times: The Traces of Foucault's Ethics.' Organization 9(4): 683-701.

Chia, Robert C. H. Holt, Robin. (2009) Strategy without Design : The Silent Efficacy of Indirect Action. Cambridge, UK; New York: Cambridge University Press.

Clegg, S. (1989) Frameworks of power. London: Sage Publications. 
Clegg, S. (1998) Foucault, Power and Organizations. In: McKinlay A and Starkey K (eds) Foucault, Management and Organization Theory. London: Sage Publications: 29-48

Collier, S. (2009) ‘Topologies of Power: Foucault's Analysis of Political Government beyond “Governmentality", Theory, Culture and Society 26(6): 78-108.

Courpasson, D. and Françoise D. (2013) 'Cultures of Resistance in the Workplace', in The SAGE Handbook of Power, edited by Stewart Clegg and Mark Haugaard, 332-347. London: SAGE.

Crane, A., Knights, D. and Starkey, K. (2008) 'The Conditions of Our Freedom', Business Ethics Quarterly 18, no. 3: 299-320.

Cummings, S. (1993) 'Brief Case: The First Strategists', Long Range Planning 26(3): 133 135.

Cummings, S. (2002) 'Recreating Strategy', London: Sage Publications.

Cummings, S. and Daellenbach, U. (2009) 'A Guide to the Future of Strategy?the History of Long Range Planning', Long Range Planning Long Range Planning 42(2): 234-263.

David-Ménard, M. (2008) 'Agencements deleuziens, dispositifs foucaldiens', Rue Descartes, 59(1): 43-55.

Davidson, A. (2009) 'Introduction'. In: Michel Foucault: Security, Territory, Population. Lectures at Collège de France 1977-1978. New York: Palgrave, pp. xvii-xxxii.

Deleuze, G. (1988) Bergsonism. New York: Zone Books.

Deleuze, G. (1989) 'Qu'est-ce qu'un dispositif?', in Michel Foucault philosophe. Rencontre internationale. Paris: Éditions du Seuil: 185-195.

Deleuze, G. (1990) 'Post-scriptum sur les sociétés de contrôle', in Deleuze, G. Pourparlers. Paris: Éditions de Minuit.

Deleuze, G. (1992) 'What is a dispositif ?', in Armstrong, T.J. (1992) Michel Foucault Philosopher. New York: Harvester Wheatsheaf: 159-169. 
Deleuze, G. (1995) 'Postscript on Control Societies', in Deleuze, G. Negotiations. (19721990. New York: Columbia University Press.

Deleuze, G. (1996) 'L'Actuel Et Le Virtuel', in Dialogues, edited by G. Deleuze and C. Parnet. Flammarion: Paris ed., 177-185.

Deleuze, G. and Guattari, F. (1988) A Thousand Plateaus : Capitalism and Schizophrenia. London: Athlone Press.

Dillon, M. (2007) 'Governing through contingency: The security of biopolitical governance', Political Geography, 26: 41-47.

Dillon, M. and Lobo-Guerrero, L. (2008) 'Biopolitics of security in the $21^{\text {st }}$ century: an introduction', Review of International Studies, 34(02): 265-292.

Dillon, M. and Lobo-Guerrero, L. (2009) 'The biopolitical imaginary of species-being', Theory, Culture \& Society, 26(1): 1-23.

Dreyfus, H. and Rabinow, P. (1982) Michel Foucault: Beyond Structuralism and Hermeneutics. Chicago: The University of Chicago Press.

Dreyfus, H. L., Rabinow, P. and Foucault, M. (1983) Michel Foucault, Beyond Structuralism and Hermeneutics. University Of Chicago Press.

Elden S. (2007) 'Rethinking governmentality’, Political Geography 26: 29-33.

Fairclough, N. (2010) 'Discourse Analysis in Organization Studies: The Case for Critical Realism', in Sage Directions in Organization Studies, edited by S.R. Clegg. Vol. 2, 273 300. London: Sage.

Fleming, P. and Spicer. A. (2004) "“You Can Check Out Anytime, but You Can Never Leave": Spatial boundaries in a high commitment work place', Human Relations 57(1): 75 94.

Foucault, M. (1975) Surveiller et punir. Paris: Éditions Gallimard. 
Foucault, M. (1976) La volonté de savoir. Paris: Gallimard.

Foucault, M. (1977) 'Le jeu de Michel Foucault', in Foucault, M. Dits et écrits III. Paris: Gallimard: 298-329.

Foucault, M. (1977) Discipline and Punish. The Birth of the Prison. London: Penguin Books.

Foucault, M. (1980) 'Table ronde du 20 mai 1978', in Perrot, M. (ed) L'impossible prison. Paris: Éditions du Seuil: 40-56.

Foucault, M. (1982) 'Afterword: the subject and power', in Dreyfus, H.L and Rabinow, R. (eds) Michel Foucault: beyond structuralism and hermeneutics. Chicago, IL: The University of Chicago Press : 208-266.

Foucault, M. (1982) 'The Subject and Power', Critical Inquiry 8(4): 777-795.

Foucault, M. (1983) ‘Structuralism and Post-Structuralism', in Faubion J (ed) (1994) Aesthetics, Method, and Epistemology. London: Penguin Books: 433-58.

Foucault, M. (1984a) 'Du pouvoir', in L'Express NO 1722, Paris: L'Express: 56-68.

Foucault, M. (1984b) 'Deux essais sur le sujet et le pouvoir', in Dreyfus, H.L ; Rabinow,R. (eds) Michel Foucault: un parcours philosophique. Paris: Gallimard : 297-321.

Foucault, M. (1996) 'Problematics', in Foucault Live. Collected Interviews, 1961-1984. Lotringer: 416-22

Foucault, M. (1997) Il faut défendre la société. Cours au Collège de France. 1976. Paris: Gallimard/Seuil.

Foucault, M. (1998) The Will to Knowledge. The History of Sexuality I. London: Penguin Books.

Foucault, M. (2001) Herméneutique du sujet. Cours au Collège de France. 1981-1982. Paris: Gallimard/Le Seuil. 
Foucault, M. (2003) Le pouvoir psychiatrique. Cours au Collège de France. 1973-1974. Paris: Gallimard/Le Seuil.

Foucault, M. (2003) Society must be defended. Lectures at the Collège de France 1975-76. New York: Picador.

Foucault, M. (2004a) Sécurité, territoire, population. Cours au Collège de France. 19771978. Paris: Gallimard/Le Seuil.

Foucault, M. (2004b) Naissance de la biopolitique. Cours au Collège de France. 1978-1979. Paris: Gallimard/Le Seuil.

Foucault, M. (2005) The Hermeneutics of the Subject. Lectures at the Collège de France 1981-1982. New York: Palgrave Macmillan.

Foucault, M. (2006) Psychiatric Power. Lectures at the Collège de France 1973-74. New York: Palgrave Macmillan.

Foucault, M. (2007) Security, Territory, Population. Lectures at the Collège de France 19771978. New York: Palgrave Macmillan.

Foucault, M. (2008) Le gouvernement de soi et des autres. Cours au Collège de France. 1972-1973. Paris: Gallimard/Le Seuil.

Foucault, M. (2008) The Birth of Biopolitics. Lectures at the Collège de France 1978-1979. New York: Palgrave Macmillan.

Foucault, M. (2010) The Government of the Self and Others, Lectures at the Collège de France (1982-83. New York: Picador.

Fournier, V. and Grey, C. (2000) 'At the Critical Moment: Conditions and Prospects for Critical Management Studies', Human Relations 53(1): 7-32.

Hassard, J. and Rowlinson, M. (2002) 'Researching Foucault's Research: Organization and Control in Joseph Lancaster's Monitorial Schools', Organization 9(4): 615-639. 
Hassard, J., Hogan, J. and Rowlinson, M. (2001) 'From Labor Process Theory to Critical Management Studies', Administrative Theory \& Praxis (Administrative Theory \& Praxis) 23(3): 339-362.

Haugaard M. (2012a) 'Editorial: Reflections upon Power Over, Power to, Power with, and the Four Dimensions of Power', J.Polit.Power Journal of Political Power 5(3): 353-358. Haugaard M. (2012b) 'Rethinking the Four Dimensions of Power: Domination and Empowerment', J.Polit.Power Journal of Political Power 5(1): 33-54.

Jackson, N. and Carter, P. (1998) 'Labour as Dressage', in Foucault, Management and Organization Theory, edited by A. McKinlay and K. Starkey, 49-64.

Jacques, R. (1996) Manufacturing the employee: Management knowledge from the (19th to 21st centuries. London: Sage Publications.

Jacquinot-Delaunay G. and Monnoyer L. (eds) (1999) 'Le dispositif - entre usage et concept', Hermés 25.

Jäger, S. (2001) 'Dispositiv', in Kleiner, M. (ed) Michel Foucault. Eine Einführung in sein Denken. Frankfurt a.M: Campus: 72-89.

Jones, C. (2002) 'Foucault's Inheritance/Inheriting Foucault', Culture and Organization 8(3): 225-38.

Jones, C. and Munro, R. (2005) 'Organization Theory, 1985-2005', in Jones, C. and Munro, R. (eds) Contemporary Organization Theory. Norwich: Blackwell Publishing: 1-15.

Katarzyna K. and McKernan, J.F. (2011) 'From Care of the Self to Care for the Other: Neglected Aspects of Foucault's Late Work', Accounting, Auditing \& Accountability Journal 24(3): 377-402. 
Knights, D. (1992) 'Changing Spaces: The Disruptive Power of Epistemological Location for the Management and Organisational Sciences', Academy of Management Review 17(3): 514-536.

Knights, D. (2002) 'Writing Organizational Analysis into Foucault', Organization 9(4): 575590.

Knights, D. and Morgan, G. (1991) 'Corporate Strategy, Organizations, and Subjectivity: A Critique', Organization Studies 12(2): 251-273.

Knights, D. and Willmott, H. (1989) 'Power and Subjectivity at Work: From Degradation to Subjugation in Social Relations', Sociology 23(4): 535-558.

Leclercq-Vandelannoitte, A. (2011) 'Organizations as Discursive Constructions: A Foucauldian Approach', Organization Studies 32(9): 1247-1271.

Legg, S. (2011) 'Assemblage/apparatus: using Deleuze and Foucault', Area 43(2): 128-133. Leibniz, G.W. (1898) Leibniz. the Monadology and Other Philosophical Writings. Oxford: Clarendon Press.

Lopdrup-Hjorth, T. (2013) 'Let's go Outside': The Value of Co-Creation. PhD Dissertation. MPP, OMS, Copenhagen Business School.

Lyotard, J.F. (1973) Des dispositifs pulsionnels. Paris: Union Générale d'Éditions.

Martinez, D. E. (2010) 'Beyond Disciplinary Enclosures: Management Control in the Society of Control', Critical Perspectives on Accounting, 22(2): 200-211.

McKinlay, A. (2002) “"Dead Selves”: The Birth of the Modern Career', Organization 9(4): $595-614$.

McKinlay, A. and Starkey, K. (1998) 'Managing Foucault: Foucault, Management and Organization Theory', in McKinlay, A. and Starkey, K. Foucault, Management and Organization Theory. London: Sage Publications: 1-28 
McKinlay, A. and Starkey, K. (1998) Foucault, Management and Organization Theory: From Panopticon to Technologies of Self. London: Sage Publications.

McKinlay, A. and Wilson, J. (2012) “"All they lose is the scream”: Foucault, Ford and mass production', Management and Organizational History 7(1): 45-60.

McKinlay, A., Carter, C. and Pezet, E. (2012) 'Governmentality, power and organization', Management and Organizational History 7(1): 3-15.

Meunier J.P. (1999) 'Dispositif et théories de la communication: Deux concepts en rapport de codétermination', Hermés 25: 83-91.

Mintzberg, H. (1994) The Rise and Fall of Strategic Planning. London: Prentice Hall.

Mintzberg, H. and Waters, J.A. (1985) Of Strategies, Deliberate and Emergent. Chichester: Wiley.

Morriss, P. (1987) Power: A philosophical analysis. New York: St. Martin's Press.

Morriss, P. (2012) 'A Response to Pamela Pansardi', Journal of Political Power 5(1): 91-99.

Muller, B.J. (2008) 'Securing the Political Imagination: Popular Culture, the Security Dispositif and the Biometric State', Security Dialogue 39(2-3): (199-220.

Mumby, D.K. (2005) 'Theorizing Resistance in Organization Studies: A Dialectical Approach', Management Communication Quarterly 19(1): 19-44.

Munro, I. (2000) 'Non-Disciplinary Power and the Network Society', Organization, 7(4): 679-695.

Newton, T. (1998) 'Theorizing Subjectivity in Organizations: The Failure of Foucauldian Studies?', Organization Studies 19(3): 415-447.

O’Connor, D. (1997) 'Lines of (f)light: The visual apparatus in Foucault and Deleuze', Space and Culture, 1: 49-66.

OED (2009) Oxford English Dictionary 2009.

P·R (2008) Le Petit Robert 2008. 
Pansardi P. (2012) 'Power to and Power Over: Two Distinct Concepts of Power?', Journal of Political Power 5(1): 73-89.

Pansardi, P. (2012) 'On Abilities and Power again: A Reply to Peter Morriss', Journal of Political Power 5(3): 493-497.

Parker, M. and Thomas, R. (2011) 'What is a critical journal?', Organization 18(4): 419-427.

Presskorn-Thygesen, T. (2012) 'Normativity And The World Of Capital', Preliminary chapter for PhD.-dissertation presented November 2012. Copenhagen: Copenhagen Business School.

Rabinow, P. (2003) Anthropos today: reflections on modern equipment. Princeton: Princeton University Press.

Rabinow, P. and Rose, N. (2003) 'Foucault Today’, in The Essential Foucault: Selections from The Essential Works of Foucault, 1954-1984. New York: New Press.

Raffnsøe, S and Staunæs, D. (2014) 'Learning to stay ahead of time: moving leadership experiences experimentally', Ahead of Time. Management \& Organizational History: 184201.

Raffnsøe, S. (1996) 'Reorganizing Society', in Karlsson \& Jonsson (eds) Law, Justice and the State. Berlin: Archiv Für Rechts- Und Sozialphilosophie.

Raffnsøe, S. (2002) 'Order Ordealed. Norms and Social Coherence in the Age of Law', Roskilde: Reading in Philosophy and Science Studies 1.

Raffnsøe, S. (2013) 'Beyond Rule, Trust and Power as Capacities', Journal of Political Power 6(2).

Raffnsøe, S. (2013) 'Beyond Rule; trust and power as capacities', Journal of Political Power 6: 2: $241-260$. 
Raffnsøe, S., Dalsgaard, M and Gudmand-Høyer, M.T. (2014) 'Kierkegaard', in Oxford Handbook of Porcess Philosophy and Organization Studies, edited by D. Hjorth and T. Hernes. Oxford: Oxford University Press.

Raffnsøe, S., Gudmand-Høyer, M. and Thaning, M. (2015) Foucault. A Research Companion. New York: Palgrave Macmillan.

Rowlinson, M. and Carter, C. (2002) 'Foucault and History in Organization Studies', Organization 9(4): 527-547.

Senellart M. (2007) 'Course Context', in M. Foucault: Security, Territory, Population. Lectures at Collège de France 1977-1978. New York: Palgrave, pp. 369-402.

Sewell, G. (1998) 'The discipline of teams: The control of team-based industrial work through electronic and peer surveillance', Administrative Science Quarterly 43(2): 397428.

Sewell, G. (2005) 'Nice Work? Rethinking managerial control in an era of knowledge work', Organization 12(5): 685-704.

Sloterdijk, P. (2009) Du Musst Dein Leben Ändern : Über Anthropotechnik. Frankfurt am Main: Suhrkamp.Smith, P. (2008) 'Meaning and Military Power: Moving on from Foucault', Journal of Power 1(3): 275-293.

Sørensen, B.M., Spoelstra, S., Höpfl, H. and Critchley, S. (2012) 'Theology and organization', Organization 19: 267-279.

Spicer, A. and Böhm, S. (2007) 'Moving Management: Theorizing Struggles Against the Hegemony of Management', Organization Studies 28(11): 1667-1698.

Spicer, A., Alvesson, M. and Kärreman, D. (2009) 'Critical Performativity: The Unfinished Business of Critical Management Studies', Human Relations 62(4): 537-560.

Starkey, K.P. and Hatchuel, A. (2002) 'The Long Detour: Foucault's History of Desire and Pleasure', Organization 9(4): 641-656. 
Thomas, R. and Davies, A. (2005) 'Theorizing the Micro-Politics of Resistance: New Public Management and Managerial Identities in the UK Public Services', Organization Studies 26(5): 683-706.

Townley, B. (1993) 'Foucault, Power/Knowledge, and Its Relevance for Human Resource Management', The Academy of Management Review 18(3): 518-45.

Townley, B. (1994) Reframing Human Resource Management: Power, Ethics and the Subject at Work. London: Sage.

Townley, B. (1995a) ““Know Thyself”: Self-Awareness, Self-Formation and Managing', Organization 2(2): 271-289.

Townley, B. (1998) 'Beyond Good and Evil: Depth and Division in the Managent of Human Resources', in Foucault, Management and Organization Theory : From Panopticon to Technologies of Self, 191-210. London: Sage Publications Ltd.

Townley, B. (2002) ‘Managing with Modernity’, Organization 9(4): 549-573

Usdiken, B. and Pasadeos, Y. (1995) 'Organizational analysis in North America and Europe: A comparison of co-citation networks', Organization studies 16(3): 503.

Välikangas, A. and Seeck, H. (2011) 'Exploring the Foucauldian interpretation of power and subject in organizations', Journal of Management \& Organization 17(6): 812-827.

Villadsen, K. (2008) 'Doing without state and civil society as universals: "Dispositifs" of care beyond the classic sector divide', Journal of Civil Society 4(3): 171-191.

Weiskopf, R. and Loacker, B. (2006) ““A snake's coils are even more intricate than a mole's burrow.” Individualization and Subjectification in Post-disciplinary Regimes of Work', Management Revue 17(4): 395-419.

Weiskopf, R. and Munro, I. (2012) 'Management of human capital: Discipline, security and controlled circulation in HRM', Organization 19(6): 685-702. 
Wray-Bliss, E. (2002) 'Abstract Ethics, Embodied Ethics: The Strange Marriage of Foucault and Positivism in Labour Process Theory', Organization 9(1): 5-39.

Author biography

Sverre Raffnsøe, dr. phil., holds a doctoral degree in philosophy and a position as Professor of Philosophy with the Department of Management, Politics and philosophy at Copenhagen Business School. He is editor-in-chief of Foucault Studies and Research Director of the crossdisciplinary research programme The Human Turn. He is the author of books and articles on philosophical aesthetics, management philosophy, social philosophy, and recent French and German philosophy. His work has appeared in Journal of Political Power and Management and Organizational History. Recent and forthcoming books include The Human Turn: The Makings of a Contemporary Relational Topography and The Aesthetic Turn. His academic home page is found at www.cbs.dk/en/staff/srampp and his personal home page at www.raffnsøe.com.

Marius Gudmand-Høyer, $\mathrm{PhD}$, is Assistant Professor in Philosophy at the Copenhagen Business School. His main areas of research are the human turn in contemporary psychiatric practice and theory and Michel Foucault's work, but he has also published work on problems pertaining to mental illness and modern work life and historical problematization analysis.

Morten S. Thaning, PhD, is Associate Professor in Philosophy at the Copenhagen Business School. His main area of research is philosophical hermeneutics, but he also has published work on Ancient Philosophy (Plato and Aristotle), phenomenology (Heidegger), philosophy of the social (Foucault) and contemporary American Idealism (John McDowell and Robert 
Brandom). He is currently writing a book on a hermeneutical conception of freedom and he is also engaged in the research project Selfunderstanding and Selfalienation - Existential Hermeneutics and Psychopathology, funded by the Velux Foundation.

The three authors are currently writing a book titled Michel Foucault: A Research Companion, scheduled for publication in 2015 by Palgrave McMillan. 